\title{
ANTHOCYANIN AND ANTHOCYANIDIN CONTENT OF HIGHBUSH BLUEBERRIES CULTIVATED IN BRAZIL
}

\author{
JÚLIA RIBEIRO SARKIS * \\ ISABEL CRISTINA TESSARO ** \\ LIGIA DAMASCENO FERREIRA MARCZAK **
}

\begin{abstract}
The objective of this study was to apply a HPLC methodology for qualitative and quantitative analysis of the six anthocyanidins present in fruits and to analyze the anthocyanin and anthocyanidin content of blueberries cultivated in Southern Brazil. The samples used belong to highbush blueberries (Vaccinium corymbosum) cultivars. Total anthocyanin content was determined by the $\mathrm{pH}$ differential method and an HPLC gradient elution system with $\mathrm{C}_{18}$ column and UV-Vis detection at $520 \mathrm{~nm}$ were used for separation and quantification of the anthocyanidins. Total anthocyanin content was of $128 \pm 3 \mathrm{mg}$ per $100 \mathrm{~g}$ of fresh pulp. Blueberry pulp presented $55 \%$ of delphinidin, $8 \%$ of cyanidin, $3 \%$ of peonidin and $34 \%$ of malvidin. Pelargonidin was not identified in the sample and petunidin was below the limits of quantification. The results were similar to those reported in studies using North American and European blueberries.
\end{abstract}

* Ph.D student in the area of heat and mass transfer, Chemical Engineering Departament, Universidade Federal do Rio Grande do Sul (UFRGS), Porto Alegre, RS (e-mail: julia@enq.ufrgs.br).

** Professor, Chemical Engineering Departament, UFRGS, Porto Alegre, RS (e-mail: isabel@enq.ufrgs.br; ligia@eng.ufrgs.br). 


\section{INTRODUCTION}

Blueberries (Vaccinium spp.) have high anthocyanins content, presenting elevated radicalscavenging activity and being potent antioxidants (PRIOR et al., 1998; ZHENG \& WANG, 2002). Researches suggest that anthocyanins in fruits and vegetables, and their antioxidant capacity, contribute to lower the risk and to treat chronic and degenerative diseases (BRAVO, 1998; KOWALCZYK et al., 2003; KONCZAK \& ZHANG, 2004). Cumulative research shows the influence of these compounds in reversing age-related deficits such as memory and locomotion (RAMIREZ et al., 2005), reducing the risk of diabetes and obesity (GRACE et al., 2009; VUONG et al., 2009) and inhibiting proliferation of cancer cells (KAMEl et al., 1998; HAGIWARA et al., 2001; SEERAM, ZHANG \& NAIR, 2003). For these reasons this fruit is seen as a very appealing option to consumers interested in functional foods.

The basic structure of an anthocyanin molecule consists of glycosylated polyhydroxyl or polymethoxyl derivatives of the flavylium cation. This basic structure, with no glucose substituents, is called anthocyanidin or aglycone and can be obtained by acid hydrolysis. This process reduces the complex pattern of anthocyanins to six major anthocyanidins: delphinidin, cyanidin, pelargonidin, peonidin, petunidin and malvidin. The anthocyanidin quantification and qualification of blueberries have been reported in limited papers (NYMAN \& KUMPULAINEN, 2001; YUE \& XU, 2008; QUEIROZ et al., 2009; OLIVEIRA et al., 2010) and these studies only refer to blueberries cultivated in Europe and North America, where these fruits are originally from.

Blueberry culture is currently cultivated in Brazil, with the cultivars belonging to the groups: rabbiteye, highbush and southern highbush. The highbush group is the most important commercial variety in Europe and the United States (PAGOT \& HOFFMAN, 2003; VIZZOTO \& PEREIRA, 2009). Brazilian blueberry production is of approximately $60 \mathrm{t}$ per year, occupying a 35 ha area, being 20 ha in the state of Rio Grande do Sul, mainly in the region of Vacaria. This region was pioneer in blueberry production in the 1990's and became a reference of this culture in Brazil (PAGOT, 2006; SANTOS et al., 2007).

Blueberry culture has adapted well to Southern Brazil weather, representing an interesting alternative for exportation and national consumption (PAGOT, 2006; SANTOS et al., 2007). The objective of this study was to apply a High Performance Liquid Chromatography (HPLC) methodology for qualitative and quantitative analysis of the six anthocyanidins present in fruits and to analyze the anthocyanin and anthocyanidin content of blueberries (Vaccinium corymbosum) cultivated in the Southern Brazil.

\section{MATERIAL AND METHODS}

Highbush blueberries (Vaccinium corymbosum) from the region of Vacaria, in Southern Brazil were used in the experiments. The fruits belong to two different cultivars, being a mixture of Bluecorp and Darrow. The samples, previously cleaned and frozen, were bought from Italbraz Company (Vacaria, Brazil) and kept at $-18{ }^{\circ} \mathrm{C}$ until analysis. A blueberry pulp was elaborated by grinding the blueberries and diluting the samples to adjust the total solids content to $16 \%$. The pulp presented $\mathrm{pH}$ value of $3.18 \pm 0.01$ and a soluble solids content ( ${ }^{\circ} \mathrm{Brix}$ ) of $13.0 \pm 0.5$.

Standards of cyanidin, delphinidin, peonidin, petunidin, malvidin and pelargonidin were purchased from Sigma Aldrich (St. Louis, United States). HPLC grade solvents including acetonitrile, methanol, o-phosphoric acid, acetic acid, and chloridric acid were obtained from Vetec (Duque de Caxias, Brazil). All experiments described in this work were performed at the Chemical Engineering Department of the Federal University of Rio Grande do Sul (BRAZIL). 


\subsection{SAMPLE PREPARATION}

The anthocyanins were extracted from a $2 \mathrm{~g}$ sample with $20 \mathrm{~mL}$ of acidified methanol $(0.01 \%, \mathrm{v} / \mathrm{v} \mathrm{HCl})$ by homogenizing for $1 \mathrm{~h}$ in a shaker (Marconi, Brazil). The sample was centrifuged for 20 min at $4 \mathrm{C}$ and $4757 \mathrm{~g}$ and the supernatant was collected. At this stage, the solids were in a pale brown color. The flasks containing the samples were flushed with Nitrogen for 2 min before storage. All sample preparation procedures were performed avoiding light and temperatures above $20^{\circ} \mathrm{C}$ in order to prevent degradation of the pigments (DURST \& WROLSTAD, 2001).

\subsection{DETERMINATION OF TOTAL ANTHOCYANIN CONTENT}

The methanolic extract, as described above, was used in the determination of the total anthocyanin content by the pH differential method (GIUSTI \& WROLSTAD, 2001; LEE, DURST \& WROLSTAD, 2005). Samples were diluted in pH 1.0 and pH 4.5 buffers, and the absorbance was measured at 510 and $700 \mathrm{~nm}$ in a Spectrophotometer (Pro-Analise, UV-Visible 1600, Brazil). Anthocyanin content was expressed based on cyanidin-3-glucoside with molar extinction coefficient of $26.900 \mathrm{~L} / \mathrm{mol} \cdot \mathrm{cm}$ and molar weight of $449.2 \mathrm{~g} / \mathrm{mol}$. Analysis was performed in duplicate and the resultant values were expressed in terms of $\mathrm{mg}$ of anthocyanin per $100 \mathrm{~g}$ of fresh pulp.

\subsection{ACID HYDROLYSIS}

Acid hydrolysis was performed according to the methodology of Rodriguez-Saona and Wrolstad (2001) with the modifications proposed by Lima et al. (2006). The methanolic solution, prepared as described in section 2.1 , was used to hydrolyze the anthocyanins to aglycons, adding $3 \mathrm{~mL}$ of sample solution to a $10 \mathrm{~mL}$ of a $2 \mathrm{~mol} / \mathrm{L} \mathrm{HCl}$ solution. The flask was wrapped in aluminum foil, flushed with Nitrogen for 2 min and immersed in boiling water for $1 \mathrm{~h}$. After hydrolysis, the samples were cooled in an ice bath in the dark for 10 min prior to use.

The hydrolyzed extract was passed through a sorbent $\mathrm{C}_{18}$ solid phase extraction (SPE) cartridge (Waters Associates, Milford, United States) which was previously activated with acidified methanol $(0.01 \%, \mathrm{v} / \mathrm{v} \mathrm{HCl})$ followed by $0.01 \%(\mathrm{v} / \mathrm{v})$ aqueous $\mathrm{HCl}$. Anthocyanidins were adsorbed onto the cartridge and water soluble compounds were washed off. The pigments were eluted using acidified methanol $(0.01 \%, \mathrm{v} / \mathrm{v} \mathrm{HCl})$ which was subsequently evaporated using Nitrogen flux until a more concentrated sample was obtained. The sample solution was filtered through a $0.45 \mu \mathrm{m}$ membrane filter (Milipore) and $20 \mu \mathrm{L}$ were injected for HPLC analysis.

\subsection{HPLC}

The HPLC analysis was performed on a PerkinEImer chromatograph system (series 200) equipped with a quaternary pump, an UV-Vis detector and a column oven (PerkinElmer, series 200). Separation was conducted on a $C_{18}$ reversed-phase, $5 \mu \mathrm{m}(250 \times 4.6 \mathrm{~mm}$ i.d., PerkinElmer) column coupled to a $\mathrm{C}_{18}, 5 \mu \mathrm{m}(15 \times 3.2 \mathrm{~mm}$ i.d., PerkinElmer) guard column. The injection volume was $20 \mu \mathrm{L}$, the detection was done at the wavelength of $520 \mathrm{~nm}$ and the temperature and flow rate were controlled at $30{ }^{\circ} \mathrm{C}$ and $1 \mathrm{~mL} / \mathrm{min}$, respectively. Gradient elution was performed according to Durst and Wrolstad (2001) using as eluent A $100 \%$ acetonitrile and as eluent B $10 \%$ acetic acid/5\% acetonitrile/1 \% phosphoric acid ( $\mathrm{v} / \mathrm{v} / \mathrm{v})$ in Mili-Q water. The modified gradient elution program was performed as follows: linear gradient from $5 \%$ A and $95 \%$ B to $20 \% A$ and $80 \%$ B, $0-20$ min; linear gradient from $20 \% A$ and $80 \%$ B to $5 \%$ A and $95 \%$ B, $20-25$ min; post-time 1 min before next injection.

\subsection{IDENTIFICATION AND QUANTIFICATION}

Identification of anthocyanidins was carried out by comparing the HPLC retention times for 
the sample and for the standards. The quantification was accomplished by using external calibration method with the concentrations being calculated using the corresponding anthocyanidin standard calibration curves. These curves were obtained by plotting the peack area versus the concentration of the standard. The mean retention times $\left(t_{R}\right)$ and the standard deviations (SD) were calculated using the values obtained from the calibration curves and are presented in Table 1 . The standard solutions were prepared by dissolving the standards in mili-Q water $(1000 \mathrm{mg} / \mathrm{L})$ and diluting to obtain solutions with different concentrations. All solutions were measured in triplicate.

\section{TABLE 1 - RETENTION TIMES ( $t_{R}$ ), LIMITS OF DETECTION (LOD) AND QUANTIFICATION (LOQ) FOR PELARGONIDIN, DELPHINIDIN, CYANIDIN, PETUNIDIN, PEONIDIN AND MALVIDIN}

\begin{tabular}{|c|c|c|c|c|c|}
\hline \multirow{2}{*}{ Anthocyanidin } & \multicolumn{2}{|c|}{$t_{R}(\min )$} & \multirow{2}{*}{$\begin{array}{c}\text { LOD } \\
(\mathrm{mg} / 100 \mathrm{~g})\end{array}$} & \multirow{2}{*}{$\begin{array}{c}\text { LOQ } \\
(\mathrm{mg} / 100 \mathrm{~g})\end{array}$} & \multirow{2}{*}{$\mathrm{R}^{2}$} \\
\hline & Mean & SD & & & \\
\hline Pelargonidin & 3.4 & 0.1 & 0.55 & 1.84 & 0.998 \\
\hline Delphinidin & 5.4 & 0.3 & 0.32 & 1.10 & 0.999 \\
\hline Cyanidin & 8.5 & 0.2 & 0.34 & 1.13 & 0.998 \\
\hline Petunidin & 10.5 & 0.2 & 0.27 & 0.89 & 0.999 \\
\hline Peonidin & 14.9 & 0.1 & 0.12 & 0.39 & 0.999 \\
\hline Malvidin & 15.5 & 0.3 & 0.66 & 2.20 & 0.998 \\
\hline
\end{tabular}

Calibration curves were satisfactory, being the peak areas of the anthocyanidins in the blueberry extract within the linear range of the curves. The concentration of anthocyanidins was further corrected according to blueberry total solids and expressed as milligrams of anthocyanidin per $100 \mathrm{~g}$ of fresh matter (FM). Analysis was performed in duplicate.

The four pointed calibration curves constructed were linear (correlation coefficients $>0.997$ ) in the ranges of: $10-90 \mathrm{mg} / \mathrm{L}$ for pelargonidin, $50-250 \mathrm{mg} / \mathrm{L}$ for delphinidin, $10-50 \mathrm{mg} / \mathrm{L}$ for cyanidin, $5-60 \mathrm{mg} / \mathrm{L}$ for petunidin and peonidin and $50-100 \mathrm{mg} / \mathrm{L}$ for malvidin. The linearity of the curves was determined using the least squares method, obtaining the angular and linear coefficients of each curve and the standard deviations of these parameters. The limits of detection (LOD) and of quantification (LOQ) for the 6 anthocyanidins analyzed are defined as 3 and 10 times, respectively, the ratio of the standard deviation of the linear coefficient to the angular coefficient of the calibration curves (SKOOG, DONALD \& HOLLER 2004). The values obtained for these limits are presented in Table 1.

For each analysis, the relative standard deviation (RSD) was determined using the least squares method in order to determine the accuracy of the methodology.

\section{RESULTS AND DISCUSSION}

Total anthocyanin content was determined using the $\mathrm{pH}$ differential method. The average anthocyanin content obtained in the experiments was $128 \pm 3 \mathrm{mg} / 100 \mathrm{~g}$ of fresh-frozen blueberry pulp with $16 \%$ solids content. The error between duplicates was $1.26 \%$. The value is within the range of 93.1 to $235.4 \mathrm{mg}$ of anthocyanins $/ 100 \mathrm{~g}$ of fresh matter reported by Prior et al. (1998) who 
studied several different cultivars of $V$. corymbosum and also in good agreement with previously reported values of $120 \mathrm{mg} / 100 \mathrm{~g}$ fresh weight (ZHENG \& WANG, 2002); $99.9 \mathrm{mg} / 100 \mathrm{~g}$ (SKREDE, WROLSTAD \& DURST, 2000a) and between 116 and $224 \mathrm{mg} / 100 \mathrm{~g}$ (YOU et al., 2011). All results mentioned above were obtained applying the $\mathrm{pH}$ differential method.

After acid hydrolysis, the anthocyanidin glycoside pattern was reduced to anthocyanidins. Figure 1 presents a chromatogram from the HPLC analysis where five well-separated and defined peaks can be observed. Peaks 1 to 5 refer to delphinidin, cyanidin, petunidin, peonidin and malvidin, respectively; these anthocyanidins were identified through comparison of the retention times. Elution order was in agreement with literature (NYMAN \& KUMPULAINEN, 2001; LIMA et al., 2006; OLIVEIRA et al., 2010) with the exception of pelargonidin which presented a lower retention time than expected. Nonetheless, previous studies (SKREDE, WROLSTAD \& DURST, 2000a; LEE, DURST \& WROLSTAD, 2002; YUE e XU, 2008; YOU et al., 2011) did not found peaks associated with pelargonidin when analyzing blueberry samples.

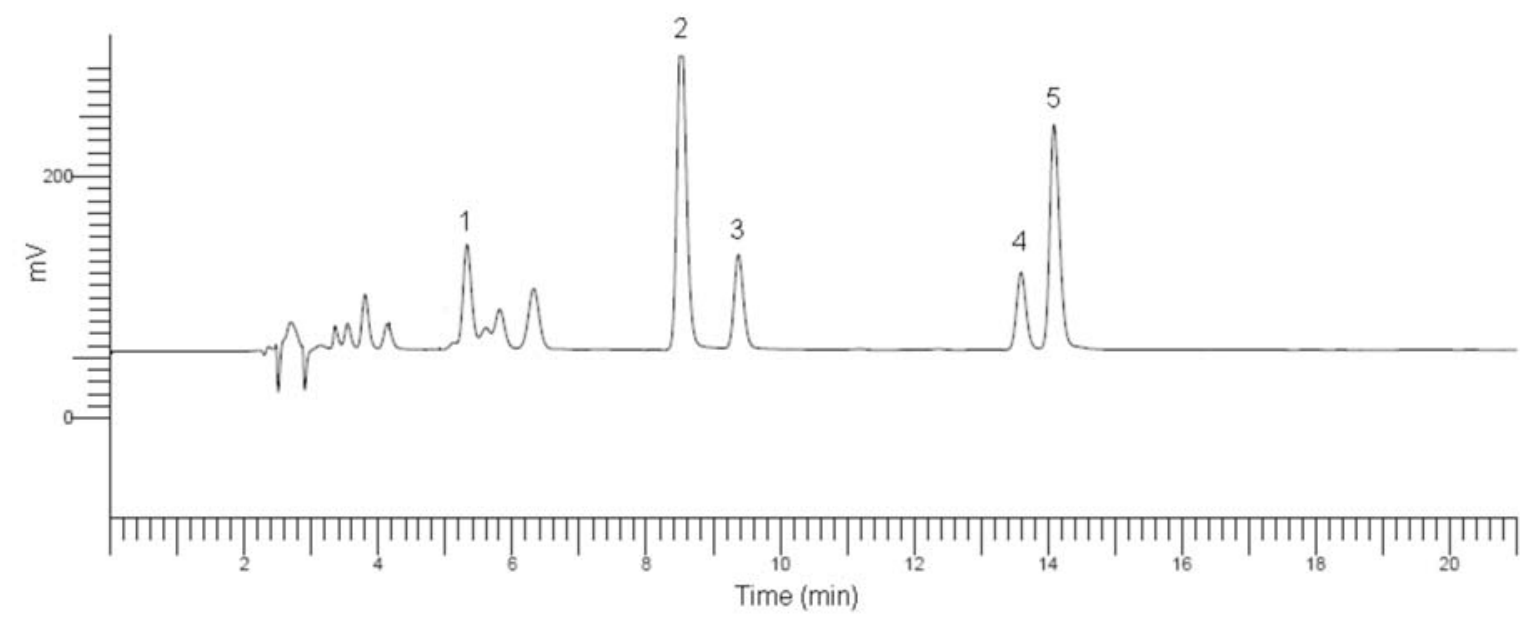

\section{FIGURE 1 - CHROMATOGRAM OF BLUEBERRY PULP}

Anthocyanidins were quantified using the calibration curves; the results for delphinidin, cyanidin, peonidin and malvidin and the standard deviation for the duplicate are presented in Table 2. The total anthocyanins in Brazilian blueberry were estimated as a sum of these four compounds. Petunidin was not quantified because its content was under the LOQ. RSD values were below $5 \%$ for all analysis. The anthocyanin content evaluated using HPLC was $143.6 \mathrm{mg} / 100 \mathrm{~g}$ of fresh matter. It must be pointed out that these values are, probably, underestimated, considering the limitations of the extraction methods (SEERAM, 2008). However, the total anthocyanins content obtained from this analysis is in agreement with research evaluating anthocyanin content in blueberries using HPLC (GAO \& MAZZA, 1994; KALT \& DUFOUR, 1997; MOYER et al., 2001). The total anthocyanin content was higher for the HPLC analysis when compared to $\mathrm{pH}$ differential method, which was also observed by Oliveira et al. (2010) and Wu et al. (2004).

The anthocyanidin composition shows the predominance of delphinidin with respect to the other anthocyanidins, followed by malvidin, cyanidin and peonidin, in this order. This result was in agreement with the study performed by Kalt et al. (1999) who evaluated several different cultivars of highbush blueberries and found that delphinidin was the major constituent among all anthocyanidins. Malvidin, however, appeared as the main anthocyanidin in the researches of Oliveira et al. (2010) and Skrede et al. (2000b) using V. corymbosum cultivars.

As a final point, it is important to emphasize that this research presents preliminary results regarding the anthocyanins content in Brazilian blueberries. Further studies, with other cultivars and 
from different regions, should be performed in order to have a broader knowledge of the blueberry culture in Brazil.

TABLE 2 - ANTHOCYANIN CONTENT IN BRAZILIAN BLUEBERRIES

\begin{tabular}{|c|c|c|c|c|}
\hline \multirow[t]{2}{*}{ Anthocyanidin } & \multirow[t]{2}{*}{ Peak no. } & \multicolumn{2}{|c|}{$\begin{array}{l}\text { Anthocyanin concentration } \\
\qquad(\mathrm{mg} / 100 \mathrm{~g} \mathrm{FM})\end{array}$} & \multirow{2}{*}{$\begin{array}{l}\text { Relative proportion } \\
(\%)\end{array}$} \\
\hline & & Mean & SD & \\
\hline Delphinidin & 1 & 78.9 & 0.5 & 54.93 \\
\hline Cyanidin & 2 & 11.9 & 0.4 & 8.31 \\
\hline Peonidin & 4 & 4.6 & 0.2 & 3.18 \\
\hline Malvidin & 5 & 48.2 & 0.4 & 33.57 \\
\hline Total & - & 144 & 2 & 100 \\
\hline
\end{tabular}

\section{CONCLUSION}

The HPLC method used in this work was considered satisfactory for anthocyanidin quantification and qualification, being possible to determine the percentage of each anthocyanidin in Brazilian blueberries.

The analysis showed delphinidin as the principal anthocyanidin, followed by malvidin, cyanidin and peonidin; the results were similar to the ones obtained in studies using North American and European blueberries.

\section{RESUMO}

\section{TEOR DE ANTOCIANINAS E ANTOCIANIDINAS EM MIRTILOS HIGHBUSH CULTIVADOS NO BRASIL}

O objetivo deste trabalho foi aplicar metodologia de Cromatografia a Líquido de Alta Eficiência (CLAE) para análise qualitativa e quantitativa das seis antocianidinas identificadas em frutas e avaliar o teor de antocianinas e antocianidinas em mirtilos highbush (Vaccinium corymbosum) cultivados no sul do Brasil. O teor total de antocianinas foi determinado pelo método do $\mathrm{pH}$ diferencial, utilizando-se sistema de CLAE com coluna $\mathrm{C}_{18}$ e detector UV-Visível no comprimento de onda de $520 \mathrm{~nm}$ para separação e quantificação das antocianidinas. O teor total de antocianinas foi de $128 \pm 3 \mathrm{mg}$ por $100 \mathrm{~g}$ de amostra em base úmida. Os resultados mostraram que a polpa de mirtilo apresentou, em média, $55 \%$ de delfinidina, $8 \%$ de cianidina, $3 \%$ de peonidina e $34 \%$ de malvidina. A pelargonidina não foi identificada na amostra e a petunidina ficou abaixo no limite de quantificação. Os resultados mostraram-se similares aos encontrados em pesquisas utilizando mirtilos provenientes da América do Norte e da Europa.

PALAVRAS-CHAVE: Vaccinium corymbosum; PERFIL DE ANTOCIANIDINAS; CLAE.

\section{REFERENCES}

1 BRAVO, L. Polyphenols: chemistry, dietary sources, metabolism, and nutritional significance. Nutrition Reviews, v.56, n.11, p.317-333, 1998.

2 DURST, R. W.; WROLSTAD, R. E. Separation and characterization of anthocyanins by HPLC. In: Wrolstad, R. E. (Ed.). Current protocols in food analytical chemistry. New York: John Wiley \& Sons, 2001. p.F1.3.1-13

3 GAO, L.; MAZZA, G. Quantitation and distribution of simple and acylated anthocyanins and other phenolics in blueberries. Journal of Food Science, v.59, n.5, p.1057-1059. 1994.

4 GIUSTI, M.M.; WROLSTAD; R.E. Characterization and measurement of anthocyanins by UV-Visible spectroscopy. 
In: WROLSTAD, R. E. (Ed.). Current protocols in food analytical chemistry. New York: John Wiley \& Sons, 2001. p.F1.2.1-13

5 GRACE, M. et al. Hypoglycemic activity of a novel anthocyanin-rich formulation from lowbush blueberry, Vaccinium angustifolium Aiton. Phytomedicine, v.16, n.5, p.406-415, 2009.

6 HAGIWARA, A. K. et al. Pronounced inhibition by a natural anthocyanin, purple corn color, of 2-amino-1-methyl-6phenylimidazo [4,5-b] pyridine (PhIP)-associated colorectal carcinogenesis in male F344 rats pretreated with 1,2dimethylhydrazine. Cancer Letters, v.171, n.1, p.17-25, 2001.

7 KALT, W.; DUFOUR, D. Health functionality of blueberries. HortTechnology, v.7, p.216-221, 1997.

$8 \mathrm{KALT}, \mathrm{W}$., et al. Anthocyanin content and profile within and among blueberry species. Canadian Journal of Plant Science, v.79, n.4, p.617-623, 1999.

9 KAMEI, H. et al. Anti-tumor effect of methanol extracts from red and white wines. Cancer Biotherapy \& Radiopharmaceuticals, v.13, n.6, p.447-452, 1998.

10 KONCZAK, I.; ZHANG, W. Anthocyanins: more than nature's colours. Journal of Biomedicine and Biotechnology, n.5, p.239-240, 2004.

11 KOWALCZYK, E. Anthocyanins in medicine. Polish Journal of Pharmacology, v.55, p.699-702, 2003.

12 LEE, J.; DURST, R.W.; WROLSTAD, R.E. Impact of juice processing on blueberry anthocyanins and polyphenolics: comparison of two pretreatments. Journal of Food Science, v.67, n.5, p.1660-1667, 2002.

13 . Determination of total monomeric anthocyanin pigment content of fruit juices, beverages, natural colorants, and

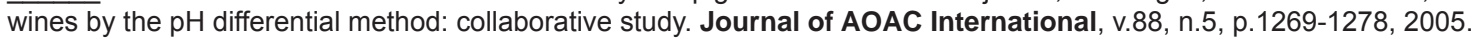

14 LIMA, V.L.A.G. et al. Anthocyanidins identification of acerola fruits from active germoplasm bank of the Rural Federal University of Pernambuco. Food Science and Technology, v.26, p.927-935, 2006.

15 MOYER, R.A. et al. Anthocyanins, phenolics, and antioxidant capacity in diverse small fruits: Vaccinium, Rubus, and Ribes. Journal of Agricultural and Food Chemistry, v.50, n.3, p.519-525, 2001.

16 NYMAN, N.A.; KUMPULAINEN, J.T. Determination of anthocyanidins in berries and red wine by high-performance liquid chromatography. Journal of Agricultural and Food Chemistry, v.49, n.9, p.4183-4187, 2001.

17 OLIVEIRA, C. et al. Cooked blueberries: anthocyanin and anthocyanidin degradation and their radical-scavenging activity. Journal of Agricultural and Food Chemistry, v.58, n.16, p.9009-9012, 2010.

18 PAGOT, E. Cultivo de pequenas frutas: amora-preta, framboesa, mirtilo. Porto Alegre: EMATER/RS - ASCAR, 2006. 41 p.

19 PAGOT, E.; HOFFMAN, A. Produção de pequenas frutas no Brasil. In: SEMINÁRIO BRASILEIRO DE PEQUENAS FRUTAS, 1., 2003. Vacaria. Anais ... Bento Gonçalves: Embrapa Uva e Vinho, 2003. 61 p.

20 PRIOR, R.L. et al. Antioxidant capacity as influenced by total phenolic and anthocyanin content, maturity, and variety of Vaccinium species. Journal of Agricultural and Food Chemistry, v.46, n.7, p.2686-2693, 1998.

21 QUEIROZ, F. Degradation of anthocyanins and anthocyanidins in blueberry jams/stuffed fish. Journal of Agricultural and Food Chemistry, v.57, n.22, p.10712-10717, 2009

22 RAMIREZ, M.R. et al. Effect of lyophilised Vaccinium berries on memory, anxiety and locomotion in adult rats. Pharmacological Research, v.52, n.6, p.457-462, 2005.

23 RODRIGUEZ-SAONA, L.E.; WROLSTAD, R.E. Extraction, isolation, and purification of anthocyanins. In: WROLSTAD, R.E. (Ed.). Current protocols in food analytical chemistry. New York: John Wiley \& Sons, 2001. p.F1.1.1-11

24 SANTOS, A.M. et al. Sistema de produção do mirtilo. Porto Alegre: Embrapa Clima Temperado, 2007.

25 SEERAM, N.P. Berry fruits: compositional elements, biochemical activities, and the impact of their intake on human health, performance, and disease. Journal of Agricultural and Food Chemistry, v.56, p.627-629, 2008.

26 SEERAM, N.P.; ZHANG, Y.; NAIR, M. G. Inhibition of proliferation of human cancer cell lines and cyclooxygenase enzymes by anthocyanidins and catechins. Nutrition and Cancer, v.46, p.101-106, 2003.

27 SKOOG, D.A.W.; DONALD, M.; HOLLER, F.J. Fundamentals of analytical chemistry. New York: Saunders College Pub., 2004

28 SKREDE, G.; WROLSTAD, R.E.; DURST, R.W. Changes in anthocyanins and polyphenolics during juice processing of highbush blueberries (Vaccinium corymbosum L.). Journal of Food Science, v.65, n.2, p.357-364, 2000. 
29 VIZZOTO, M.; PEREIRA, M. C. Metodologia científica: otimização de processo de extração de compostos fenólicos antioxidantes de mirtilo (vaccinium ashei reade). Pelotas: Embrapa Clima Temperado, 2009

30 VUONG, T. et al. Antiobesity and antidiabetic effects of biotransformed blueberry juice in KKA mice. International Journal of Obesity, v.33, n.10, p.1166-1173, 2009.

31 WU, X. et al. Characterization of anthocyanins and proanthocyanidins in some cultivars of Ribes, Aronia, and Sambucus and their antioxidant capacity Journal of Agricultural and Food Chemistry, v.52, p.7846-7856, 2004.

32 YOU, Q. et al. Comparison of anthocyanins and phenolics in organically and conventionally grown blueberries in selected cultivars. Food Chemistry, v.125, n.1, p.201-208, 2011.

$33 \mathrm{YUE}, \mathrm{X}$; $\mathrm{XU}, \mathrm{Z}$. Changes of anthocyanins, anthocyanidins, and antioxidant activity in bilberry extract during dry heating. Journal of Food Science, v.73, n.6, p.C494-C499, 2008

34 ZHENG, W.; WANG, S. Y. Oxygen radical absorbing capacity of phenolics in blueberries, cranberries, chokeberries, and lingonberries. Journal of Agricultural and Food Chemistry, v.51, n.2, p.502-509, 2002.

\section{ACKNOWLEDGEMENTS}

The authors acknowledge the financial support received from CNPq (Conselho Nacional de Desenvolvimento Científico e Tecnológico), as a scholarship to the first author, and from CAPES (Coordenação de Aperfeiçoamento de Pessoal de Nível Superior) within the PRODOC project. 